\title{
El Cineclub, una institución resistente
}

\author{
Ariel Viola \\ FHUC-UNL
}

\section{Resumen}

El cine, como arte de nuestro moderno siglo xx, recorre

Palabras clave:

la historia a través de sus maneras de manifestarse y cine, Cineclub, cultura de relacionarse con la sociedad. Devenido, hegemónicamente, en un complejo controlado y organizado por la industria, ha sabido, sin embargo, promover movimientos socioculturales que actúan en favor de preservar su faceta más artística y cultural. El Cineclub es la institución más importante en este sentido, inscribiéndose socialmente en un espacio de promoción de material audiovisual de calidad, alternativo, local y de diversidad cultural. Desde los años '9o, la ola neoliberal perjudicó a los espacios de cine más pequeños, y las salas de Santa Fe se concentraron dentro del complejo empresarial de Cinemark, emplazado en el paseo de compras de la ciudad. Cineclub Santa Fe supo resistir a esos contrarrestantes y, en la actualidad, sigue siendo una institución cultural convocante. 


\section{Abstract}

\section{The Cineclub, an enduring institution}

The cinema, as an art form of our modern twentieth century, recounts history through its ways of manifesting and interacting with society. Although it has become, hegemonically, a complex system controlled and organized by the industry, it has managed to promote sociocultural movements that help preserve its artistic and cultural side.

The Cineclub is the most important institution in this sense; it is socially included in a space for promotion of alternative, local, cultural and high quality material. Since the 90's, neoliberal policies have harmed small cinema theaters, and all the screens in Santa Fe were set up in the multiplex Cinermark, which is located in the local shopping mall. The Cineclub was able to endure those obstacles and it is still a vibrant cultural institution.

\section{Keywords:}

Cinema, Cineclub, culture
¿Qué hacemos cuando vemos una película? Mucho se puede responder sobre esta cuestión. En general podemos pensar que se busca entretener la mirada y relajar el pensamiento; o que entregamos nuestro estado de ánimo a las variadas sensaciones que despiertan; o que salimos de recreación en un tiempo libre a consumir un espectáculo audiovisual. En este trabajo se intenta abandonar la superficie y explorar la profundidad de lo que entrańa el visionado de un filme. Antes de ahondarnos en el análisis, hay que resaltar la naturaleza artística que pertenece al cine, es decir, previamente a considerarse el motivo de asistencia a un evento, «ir al cine», la obra cinematográfica es la consecución de la práctica de un arte, con todo lo que ese ejercicio significa. Pero aunque el cine sea parte de un movimiento artístico, sus gestores y su público parten de distintos intereses para difundirlo y consumirlo.

La cinematografía, como disciplina del siglo $\mathrm{xx}$, se entrecruza con los fenómenos y las nociones de nuestra era, de nuestro complejo mundo. Así, el cine se relaciona con las formas artísticas a través de sus realizadores, los directores y asistentes de filmación y producción, los cuales 